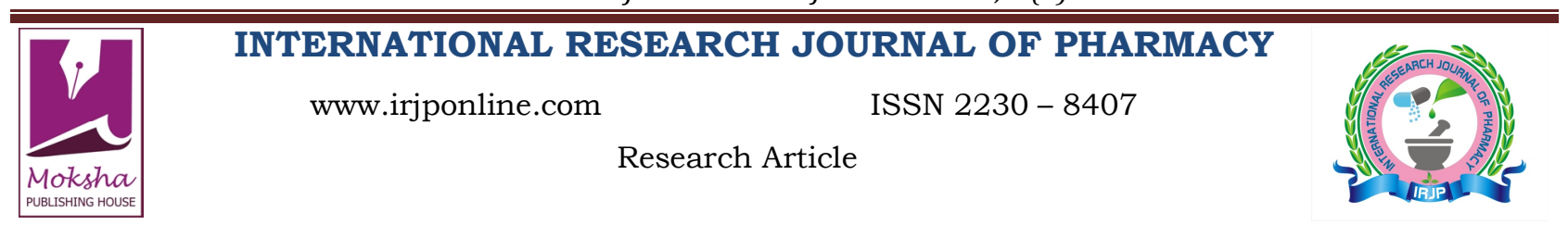

\title{
UV SPECTROPHOTOMETRIC METHOD DEVELOPMENT AND VALIDATION OF SIMULTANEOUS ESTIMATION OF CIPROFLOXACIN AND ORNIDAZOLE IN TABLET DOSAGE FORM
}

\author{
K.S. Natraj*, Y. Suvarna, G. Prasanti and S.V.Saikumar
}

Shri Vishnu College of Pharmacy, Bhimavaram, West Godavari District, Andhra Pradesh, India

*Corresponding Author Email: drnatraj@svcp.edu.in

Article Received on: 18/05/13 Revised on: 04/06/13 Approved for publication: 17/07/13

DOI: $10.7897 / 2230-8407.04739$

IRJP is an official publication of Moksha Publishing House. Website: www.mokshaph.com

(C) All rights reserved.

\section{ABSTRACT}

Three simple Spectrophotometric methods have been developed for simultaneous estimation of Ciprofloxacin and Ornidazole from tablet dosage form. Method A is Dual wavelength method, involves determination of Ciprofloxacin at the absorbance difference between $261.0 \mathrm{~nm}$ and $280.2 \mathrm{~nm}$ and ornidazole at the absorbance difference between $302.5 \mathrm{~nm}$ and $335 \mathrm{~nm}$. Method B is First order derivative spectroscopy, wavelength selected for quantitation were 262 $\mathrm{nm}$ for Ciprofloxacin (zero cross for Ornidazole) and $332 \mathrm{~nm}$ for Ornidazole (zero cross for Ciprofloxacin). Method C is Area under Curve method; AUC in the range of 268.0-274.0 nm (for Ciprofloxacin) and 316.0-322.0 nm (for Ornidazole) were selected for the analysis. The linearity lies between 2-10 $\mu \mathrm{g} / \mathrm{ml}$ and $2-20 \mu \mathrm{g} / \mathrm{ml}$ for Ciprofloxacin and Ornidazole respectively for Method A, B and C. The accuracy and precision of the methods were determined and validated statically. All the methods showed good reproducibility and recovery with low \% RSD.

Keywords: Ciprofloxacin, Ornidazole, Dual wavelength Method, First order derivative Spectroscopy, Area under curve method.

\section{INTRODUCTION}

Ciprofloxacin, chemically, 1-cyclopropyl-6-fluoro-1, 4dihydro-4-oxo- 7 (piperazin-1-yl) quinoline-3-carboxylic acid $^{1}$; belongs to the group of synthetic fluoroquinolone antibiotics with broad antimicrobial activity. Ornidazole, chemically, 1-chloro-3-(2-methyl-5nitro-1H-imidazol-1-yl) propan-2-ol, is an antimicrobial agent. Ornidazole is used in the treatment of amoebiasis and other protozoal diseases. Literature survey revealed that various analytical methods such as UV spectroscopy ${ }^{2-4}$, HPLC ${ }^{5}$, have been reported for the Simultaneous estimation of both the drugs. The UV spectrophotometric analysis is often preferred in quality control testing and ordinary laboratories due to its broader availability, suitability and ease of use. The aim of the present investigation is to develop a simple, sensitive and reproducible UV Spectrophotometric method for analysis of Ciprofloxacin and Ornidazole in a combined tablet dosage form and hence an economical method was developed and validated.

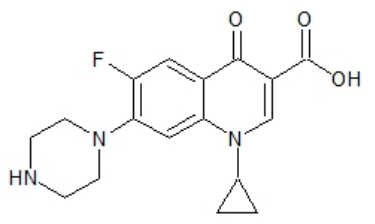

Ciprofloxacin<smiles>Cc1ncc([N+](=O)[O-])n1CC(O)CCl</smiles>

Ornidazole

\section{MATERIALS AND METHODS}

\section{Instrument Used}

A double beam UV-Visible spectrophotometer (UV lab India) with matched quartz cells was used for all spectral measurements.

\section{Chemicals and Reagents}

The tablets of the said combination were purchased from a local pharmacy (The label claim contained $500 \mathrm{mg}$ of Ciprofloxacin and $500 \mathrm{mg}$ of Ornidazole). Distilled water was used as solvent to prepare all solutions.

\section{Procedure}

Preparation of stock solution $(1000 \mu \mathrm{g} / \mathrm{ml})$

Accurately weighed quantity of pure Ciprofloxacin $(10 \mathrm{mg})$ and pure Ornidazole $(10 \mathrm{mg})$ were transferred into two separate $10 \mathrm{~mL}$ volumetric flasks, dissolved in distilled water and made up the volume to $10 \mathrm{~mL}$ with the same solvent. The stock solution was sonicated for 2 minutes.

Preparation of working standard solution $(100 \mu \mathrm{g} / \mathrm{ml})$ From the above stock solution $1 \mathrm{~mL}$ each of Ciprofloxacin and Ornidazole was taken, transferred to separate $10 \mathrm{~mL}$ volumetric flasks and the volume was made up to $10 \mathrm{ml}$ with distilled water.

\section{Method A: Dual Wave Length Method}

In this method, $10 \mu \mathrm{g} / \mathrm{ml}$ solution of standard drug Ciprofloxacin and Ornidazole were prepared using distilled water as solvent and scanned from $400 \mathrm{~nm}$ to $200 \mathrm{~nm}$ (Figure $2)$. From the absorption spectra four wave lengths $261 \mathrm{~nm}$ $(\lambda 1), 280.2 \mathrm{~nm}(\lambda 2), 302.5 \mathrm{~nm}(\lambda 3)$ and $335 \mathrm{~nm}(\lambda 4)$ were selected for analysis of both drugs. The quantitative determination of Ornidazole is carried out by measuring the absorbance difference value between $261 \mathrm{~nm}(\lambda 1)$ and 280.2 $\mathrm{nm}(\lambda 2)$ where Ciprofloxacin have same absorbance at both the wave lengths. The absorbance difference between $261 \mathrm{~nm}$ $(\lambda 1)$ and $280.2 \mathrm{~nm}(\lambda 2)$ is directly proportional to concentration of Ornidazole. The quantitative determination of Ciprofloxacin is carried out by measuring the absorbance 
difference value between $302.5 \mathrm{~nm}(\lambda 3)$ and $335 \mathrm{~nm}(\lambda 4)$ where Ornidazole have same absorbance at both the wave lengths. The absorbance difference between $302.5 \mathrm{~nm}(\lambda 3)$ and $335 \mathrm{~nm}(\lambda 4)$ is directly proportional to concentration of Ciprofloxacin. ${ }^{6}$

\section{Method B: First Order Derivative Method}

In this method, $10 \mu \mathrm{g} / \mathrm{ml}$ solution of standard drug Ciprofloxacin and Ornidazole were prepared using distilled water as solvent and scanned from $400 \mathrm{~nm}$ to $200 \mathrm{~nm}$. The absorption spectra thus obtained were derivatized from first order to fourth order. First order derivative spectra were selected for analysis of both drugs. From the overlain spectra of both the drugs (Figure 3), wavelength selected for quantification were $262 \mathrm{~nm}$ for Ciprofloxacin (zero cross of Ornidazole) and $332 \mathrm{~nm}$ for Ornidazole (zero cross of Ciprofloxacin). The calibration curve for Ciprofloxacin and Ornidazole were plotted in the concentration range of 2-10 $\mu \mathrm{g}$ $/ \mathrm{ml}$ at $262 \mathrm{~nm}$ and $332 \mathrm{~nm}$ respectively. ${ }^{7}$

\section{Method C: Area under Curve Method}

In this method, $10 \mu \mathrm{g} / \mathrm{ml}$ solution of standard drug Ciprofloxacin and ornidazole were prepared in solvent mixture and scanned from $400 \mathrm{~nm}$ to $200 \mathrm{~nm}$. From the overlain spectra of both the drugs, area under the curve in the range of 268-274 $\mathrm{nm}(\lambda 1-\lambda 2$ for Ciprofloxacin) and in the range of 316-322 $\mathrm{nm}(\lambda 3-\lambda 4$ for Ornidazole) were selected for analysis (Figure 4). The calibration curve or Ciprofloxacin and Ornidazole were plotted in the concentration range of 2-10 $\mu \mathrm{g} / \mathrm{ml}$ for both the drugs with respect to their respective area under the curve. The ' $\mathrm{X}$ ' values for both the drugs were determined at the selected AUC range. ${ }^{8}$ The ' $\mathrm{X}$ ' is the ratio of area under the curve at selected wavelength ranges with the concentration in $\mu \mathrm{g} / \mathrm{ml}$. The ' $X$ ' values were the mean of five independent determinations. A set of two simultaneous equations obtained by using mean ' $\mathrm{X}$ ' values are given below.

$$
\begin{aligned}
& \mathrm{A} 1=0.753 \mathrm{C}_{\mathrm{CIP}}+0.0731 \mathrm{C}_{\mathrm{ORN}}(\text { at } \lambda 1-\lambda 2) \text {------- (1) } \\
& \mathrm{A} 2=0.2946 \mathrm{C}_{\mathrm{CIP}}+0.309 \mathrm{C}_{\mathrm{ORN}}(\text { at } \lambda 3-\lambda 4) \text {------- (2) }
\end{aligned}
$$

Where A1 and A2 were area under curve of samples at the wavelength range $268-274 \mathrm{~nm}(\lambda 1-\lambda 2)$ and $316-322 \mathrm{~nm}(\lambda 3-\lambda 4)$ respectively

0.753 and 0.2946 were ' $X$ ' values of Ciprofloxacin in the $\lambda 1-$ $\lambda 2$ and $\lambda 3-\lambda 4$ respectively. Similarly 0.0731 and 0.309 were ' $\mathrm{X}$ ' values of Ornidazole in the $\lambda 1-\lambda 2$ and $\lambda 3-\lambda 4$ respectively. $\mathrm{C}_{\mathrm{CIP}}$ and $\mathrm{C}_{\mathrm{ORN}}$ were concentrations of Ciprofloxacin and Ornidazole respectively. The concentrations of Ciprofloxacin and Ornidazole in sample were determined by using equation (1) and (2).

\section{Estimation of Ciprofloxacin and Ornidazole in Tablet Dosage Form}

For the estimation of Ciprofloxacin and Ornidazole in commercial formulations, twenty tablets were weighed and average weight was calculated. The tablets were crushed and tablet powder equivalent to $5 \mathrm{mg}$ of Ciprofloxacin $(5 \mathrm{mg}$ Ornidazole) was transferred to a $100 \mathrm{ml}$ volumetric flask and fractions of distilled water were added up to $75 \mathrm{ml}$ with 15 minutes shaking. The solutions were sonicated in ultrasonic bath for 15 minutes. The volume was made up to $100 \mathrm{ml}$ with the distilled water and filtered through Whatman filter paper (No. 41). From the filtrate $10 \mathrm{ml}$ was transferred to a $100 \mathrm{ml}$ volumetric flask and volume was made up by distilled water to obtain $5 \mu \mathrm{g} / \mathrm{ml}$ of Ciprofloxacin and $5 \mu \mathrm{g} / \mathrm{ml}$ of Ornidazole. In method A, the concentration of Ciprofloxacin and Ornidazole were determined by measuring the absorbance of the sample at $261 \mathrm{~nm}(\lambda 1), 280.2 \mathrm{~nm}(\lambda 2)$ and $302.5 \mathrm{~nm}(\lambda 3), 335 \mathrm{~nm}(\lambda 4)$ and absorbance difference values of $\lambda 1-\lambda 2, \lambda 3-\lambda 4$ were calculated. From standard calibration curve the concentration of ciprofloxacin and Ornidazole were determined. For method B, the absorbance of the sample solution were measured at $262 \mathrm{~nm}$ (for Ciprofloxacin) and $332 \mathrm{~nm}$ (for Ornidazole) in first order derivative mode and concentration was calculated against the calibration curve. For method C, the concentration of both Ciprofloxacin and Ornidazole were determined by measuring area under curve in the range of 268-274 $\mathrm{nm}$ (for Ciprofloxacin) and 316-322 $\mathrm{nm}$ (for Ornidazole) and values were substituted in the respective equation (Equation 1 and 2) to get the concentration present in the sample solution (Table 1)

\section{Validation of the Methods}

The methods were validated with respect to linearity, accuracy, precision and selectivity.

\section{Linearity}

In case of all the three methods both the drugs Ciprofloxacin and ornidazole follow the Beer' law from $2 \mu \mathrm{g} / \mathrm{ml}-10 \mu \mathrm{g} /$ $\mathrm{ml}$ and $2 \mu \mathrm{g} / \mathrm{ml}-20 \mu \mathrm{g} / \mathrm{ml}$ respectively

\section{Accuracy}

In all the three methods the accuracy was tested by recovery study by standard addition method. The standard drugs were added to the pre - analysed marketed dosage form at three different levels i.e. $25 \%, 50 \%$ and $100 \%$ (Table 2)

\section{Precision}

The precision of the methods were tested in terms of repeatability and reproducibility. The precision of the proposed methods were performed by intra-day and inter-day assay. In intra-day assay the same sample was assayed with time interval for 6 times within the same day. In inter-day assay the assay of the samples were done on 3 consecutive days. The precision of the methods were expressed in terms of $\%$ RSD. (Table 3 )

\section{LOD and LOQ}

The LOD and LOQ (Table-4) was determined by using equation (1) and (2) respectively

$$
\begin{aligned}
& \mathrm{LOD}=3.3 \sigma / \mathrm{S} \text {------------ (3) } \\
& \mathrm{LOQ}=10 \sigma / \mathrm{S} \text {----------- (4) } \\
& \text { Where ' } \sigma \text { ' is the standard deviation of } y \text {-intercept and ' } S \text { ' is the slope of }
\end{aligned}
$$

\section{Selectivity and Specificity}

The methods were performed in presence of excipients, but there were no interference of the excipients which indicates the selectivity of the methods.

\section{RESULTS AND DISCUSSION}

The proposed methods were found to be simple, accurate and reproducible for routine simultaneous estimation of ciprofloxacin and ornidazole in combination. In all the three methods the content of both the compounds were found within the limits of IP and the lower values of Relative Standard Deviation suggests the precision of the methods. 
K.S. Natraj et al. Int. Res. J. Pharm. 2013, 4 (7)

Table 1: Analysis of Ciprofloxacin and Ornidazole in Tablet Dosage Form

\begin{tabular}{|c|c|c|c|c|c|c|}
\hline \multirow[b]{2}{*}{ Method } & \multicolumn{2}{|c|}{ Label claim (mg/tab) } & \multicolumn{2}{|c|}{ Amount found* (mg/tab) } & \multicolumn{2}{|c|}{$\%$ label claim* \pm S.D } \\
\hline & CIP & ORN & CIP & ORN & CIP & ORN \\
\hline $\mathrm{A}$ & 500 & 500 & 498.23 & 502.51 & $99.65 \pm 0.57$ & $100.5 \pm 0.36$ \\
\hline $\mathrm{B}$ & 500 & 500 & 501.25 & 502.93 & $100.25 \pm 0.49$ & $100.58 \pm 0.62$ \\
\hline $\mathrm{C}$ & 500 & 500 & 498.56 & 501.37 & $99.72 \pm 0.81$ & $100.27 \pm 0.9$ \\
\hline
\end{tabular}

*Average of five determinations, CIP-Ciprofloxacin, ORN-Ornidazole

Table 2: Results of Recovery Study

\begin{tabular}{|c|c|c|c|}
\hline \multirow[t]{2}{*}{ Method } & \multirow{2}{*}{$\begin{array}{c}\text { Level of } \\
\text { Recovery }\end{array}$} & \multicolumn{2}{|c|}{ \% Recovery* \pm S.D } \\
\hline & & CIP & ORN \\
\hline \multirow{3}{*}{ A } & $80 \%$ & $100.02 \pm 0.76$ & $100.51 \pm 0.31$ \\
\hline & $100 \%$ & $100.15 \pm 1.21$ & $100.78 \pm 0.43$ \\
\hline & $120 \%$ & $101.24 \pm 0.13$ & $100.95 \pm 0.82$ \\
\hline \multirow{3}{*}{ B } & $80 \%$ & $100.32 \pm 0.52$ & $99.99 \pm 0.19$ \\
\hline & $100 \%$ & $100.93 \pm 1.64$ & $101.50 \pm 0.33$ \\
\hline & $120 \%$ & $99.25 \pm 0.28$ & $100.41 \pm 0.91$ \\
\hline \multirow{3}{*}{$\mathrm{C}$} & $80 \%$ & $99.37 \pm 0.45$ & $101.08 \pm 0.26$ \\
\hline & $100 \%$ & $100.11 \pm 0.85$ & $100.98 \pm 0.41$ \\
\hline & $120 \%$ & $101.63 \pm 0.79$ & $98.91 \pm 1.13$ \\
\hline
\end{tabular}

Table 3: Precision Data of Ciprofloxacin and Ornidazole

\begin{tabular}{|c|c|c|c|c|c|c|}
\hline \multirow{2}{*}{ Precision } & \multicolumn{2}{|c|}{ Method A } & \multicolumn{2}{c|}{ Method B } & \multicolumn{2}{c|}{ Method C } \\
\cline { 2 - 7 } & CIP & ORN & CIP & ORN & CIP & ORN \\
\hline Intraday (\% RSD) & 0.2890 & 0.1735 & 0.5346 & 0.0714 & 0.7921 & 0.0162 \\
\hline Interday (\% RSD) & 0.2876 & 0.1801 & 0.4955 & 0.0701 & 0.8149 & 0.0183 \\
\hline
\end{tabular}

Table 4: Validation Data

\begin{tabular}{|c|c|c|c|c|c|c|}
\hline \multirow{2}{*}{ Parameters } & \multicolumn{2}{|c|}{ Method A } & \multicolumn{2}{c|}{ Method B } & \multicolumn{2}{c|}{ Method C } \\
\cline { 2 - 6 } & CIP & ORN & CIP & ORN & CIP & ORN \\
\hline Wavelengths $(\mathrm{nm})$ & $302.5-335$ & $261-280.2$ & 262 & 332 & $268-274$ & $316-322$ \\
\hline Linearity $(\mu \mathrm{g} / \mathrm{ml})$ & $2-10$ & $2-20$ & $2-10$ & $2-20$ & $2-10$ & $2-20$ \\
\hline LOD $(\mu \mathrm{g} / \mathrm{ml})$ & 0.2177 & 0.1496 & 0.3640 & 0.2253 & 0.4273 & 0.3825 \\
\hline LOQ $(\mu \mathrm{g} / \mathrm{ml})$ & 0.4630 & 0.3461 & 0.5890 & 0.4897 & 0.7318 & 0.6921 \\
\hline Slope $(\mathrm{m})$ & 0.012 & 0.004 & 0.004 & 0.00085 & 0.701 & 0.315 \\
\hline Intercept & 0.003 & 0.0001 & 0.0003 & 0.0005 & 0.26 & 0.038 \\
\hline Regression $\left(\mathrm{r}^{2}\right)$ & 0.991 & 0.993 & 0.995 & 0.989 & 0.988 & 0.992 \\
\hline
\end{tabular}

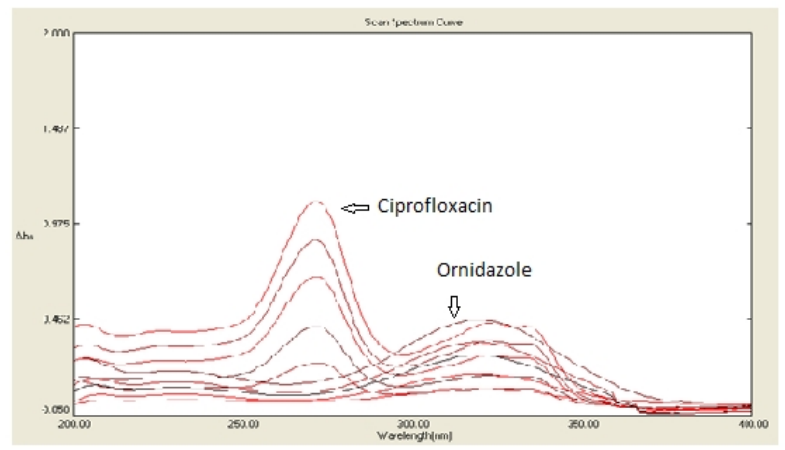

Figure 1: Overlain Zero Order Absorption Spectra of Ciprofloxacin and Ornidazole

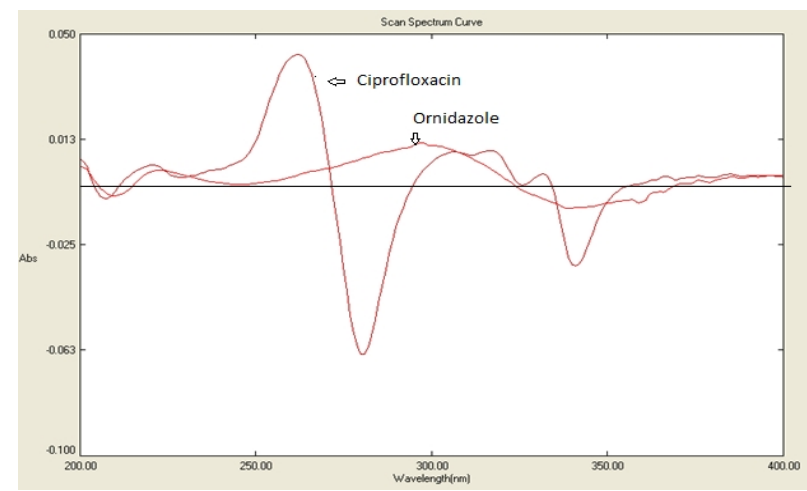

Figure 2: Overlain First Order Derivatve Spectra of Ciprofloxacin and Ornidazole 


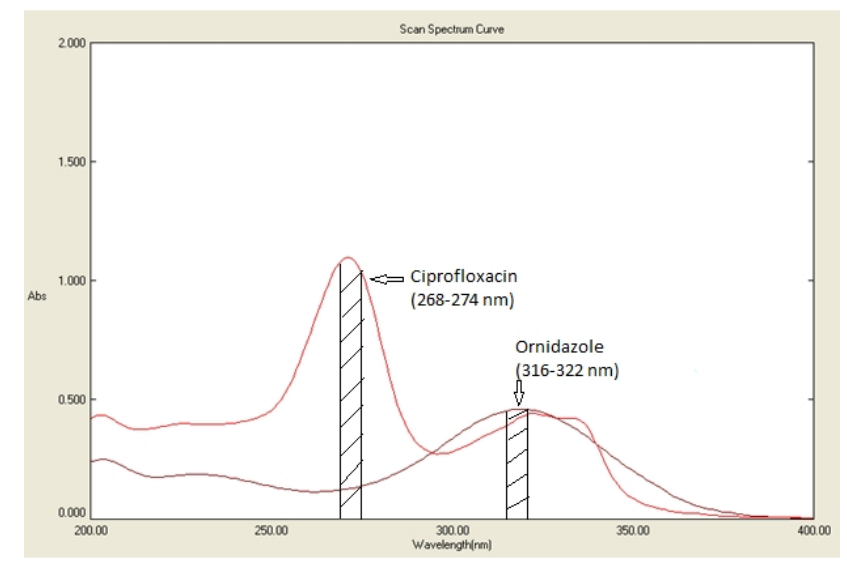

Figure 3: Overlain Spectra of Ciprofloxacin and ornidazole in Area under curve (AUC) method

\section{CONCLUSION}

All the three proposed methods are accurate, precise, rapid, reproducible and economical and can be employed for routine quality control of Ciprofloxacin and Oridazole in combined dosage formulation.

\section{ACKNOWLEDGEMENT}

The authors are very much thankful to Ranbaxy laboratories Ltd. for providing the standard drugs of Ciprofloxacin and Ornidazole. The authors are also thankful to Shri Vishnu College of Pharmacy, Bhimavaram, India

for providing the necessary research facilities for carrying out the research work.

\section{REFERENCES}

1. Beckett AH, Stenlake JB. Practical pharmaceutical chemistry; $\left(4^{\text {th }}\right.$ ed, part II) CBS publishers, New Delhi; 2005. p. 286

2. Grewal AS, Patro SK, Kanungo SK and Bhardwaj SK. Simultaneous spectrophotometric estimation of Ciprofloxacin and Ornidazole in tablet dosage form. International Journal of Pharmaceutical Sciences and Research 2012; 3(8): 2716-2720.

3. Sharma R, Pathodiya G, Mishra GP et al. A novel spectrophotometric method for quantitative determination of ciprofloxacin hydrochloride and tinidazole in tablets using hydrotropic solubilizing agent. Journal of Pharmacy Research 2011; 4(3): 859-861.

4. Gummadi Sowjanya, Devi Thota, Sri Valli Varri et al. Development and validation of UV spectroscopic methods for simultaneous estimation of ciprofloxacin and tinidazole in tablet formulation. International Current Pharmaceutical Journal 2012; 1(10): 317-321.

5. Singh Ranjit, Maithani Mukesh, Sarafa Shailendra Kumar et al. Simultaneous Estimation of Ciprofloxacin Hydrochloride, Ofloxacin, Tinidazole and Ornidazole by Reverse Phase- High Performance Liquid Chromatography. Eurasian Journal of Analytical Chemistry 2009; 4(2).

6. Goswami Jigar, Kakadiya Jagadish, Shah Nehal. Development and validation of Dual wave length UV spectrophotometric method for simultaneous estimation of Ambroxol hydrochloride and cefpodoxime proxetil in their combined tablet dosage form. International Research Journal of Pharmacy 2012; 3(4): 330-333.

7. Anindita Behera, Aurobinda Parida, Meher Amit Kumar et al. Development and Validation of Spectrophotometric method for determination of Emtricitabine and Tenefovir disiproxil fumerate in bulk and tablet dosage form. International Journal of Pharm Tech Research 2011; 3(3): 1874-1882.

8. Thomas Asha B, Jagdale Sheetal N, Dighe Shweta B et al. Simultaneous Spectrophotometric Estimation of Amlodipine Besylate and Telmisartan in Tablet Dosage form. International Journal of Pharm Tech Research 2010; 2(2): 1334-1341.

\section{Cite this article as:}

K.S. Natraj, Y. Suvarna, G. Prasanti and S.V.Saikumar. UV spectrophotometric method development and validation of simultaneous estimation of ciprofloxacin and ornidazole in tablet dosage form. Int. Res. J. Pharm. 2013; 4(7):178-181 http://dx.doi.org/10.7897/2230-8407.04739 